УДК 346.242: 341.17: 339.137.025

\title{
Андрій Бояр,
}

доктор економічних наук, професор,

завідувач кафедри міжнародних економічних відносин

та управління проєктами,

Волинський національний університет імені Лесі Українки,

ORCID ID 0000-0002-9379-8140

Andrij.Boyar@vnu.edu.ua

DOI 10.29038/2524-2679-2021-01-345-358

\section{ВПЛИВ ЄВРОПЕЙСЬКОГО СОЮЗУ НА ФОРМУВАННЯ СИСТЕМИ КОНКУРЕНТНОГО РЕГУЛЮВАННЯ В УКРАЇНІ}

Інтеграиія до Свропейського Союзу є одним із визначальних пріоритетів зовнішньої політики України з перших років ї̈ існування. Тому євроінтеграційний поступ у різних сферах життя суспільства є доволі цікавим й актуальним об'єктом дослідження та наукового обтрунтування. Сфера регулювання конкурениії не є винятком щзодо иъього. У статті досліджено базові риси системи конкурентного регулювання СС. Здійснено історико-ретроспективний аналіз еволюиії національної системи конкурентного регулювання Украӥни в контексті впливу євроінтеграиійного чинника. Установлено, що хоча ї̈ формування із самого початку відбувалося відповідно до принщипів і норм СС, до часу набуття чинності Угодою про асоиіацію між Украйною та СС (01.09.2017) існували деякірозбіжностіміж двома системами, щуо, однак, виправлено в перші три роки імплементації иієї Угоди українською стороною. Зокрема, суттєво реформовано систему надання державної допомоги в Україні (створено реєстр схем державної допомоги, приведено їх у відповідність до визначених Угодою критеріїв), збільшено порогові вартісні показники, за досягнення яких потрібно отримувати дозвіл на злиття підприємств, змінено систему визначення штрафів за порушення конкурентного законодавства, зазнали змін правові та організаційні засади діяльності Антимонопольного комітету України. Саме останній є головним відповідальним органом за виконання конкурентних норм Угоди про асоціацію. Установлено, щуо нормативно сфера регулювання конкурениії в Україні є однією з найбільш гармонізованих до стандартів ЄС сьогодні, однак практичне дотримання прийнятих 
європейських конкурентних норм залишається актуальним питанням для нашої держави.

Статтю підготовлено в межах проєкту «Студї СС у ВНУ імені Лесі Українки» програми Свропейського Союзу ERASMUS+ напряму кафедра Жана Моне (№ 611478-EPP-1-2019-1-UA-EPPJMO-CHAIR).

Ключові слова: конкуренція; Украӥна; Свропейський Союз; регулювання; система; угода; асоиіація.

\section{1. ВСТУП}

Постановка проблеми. Свропейський Союз зацікавлений у сусідстві $з$ країнами, які мають позитивну соціально-економічну динаміку, успішно розв'язують проблеми сталого розвитку. Для європейських країн з економікою, що трансформується, до яких належить й Україна, важливою передумовою такого розвитку $\epsilon$ завершення перехідного процесу, подальше зростання на основі ефективно функціонуючих ринкових механізмів, центральний елемент яких - конкуренція. Сприяння формуванню конкурентних середовищ та відповідної системи національного регулювання у країнах-сусідах є важливою метою ЄС. Водночас для України запровадження стандартів СС щодо конкурентної політики є надзвичайно актуальним і практичним питанням із позиції підготовки іï економіки до функціонування в єдиному інтегрованому європейському ринковому просторі, зокрема в контексті наявних нині зон вільної торгівлі є СС і САВТ.

Сдині правила регулювання конкуренції забезпечують конкурентоспроможності підприємств та захищають інтереси споживачів, надаючи їм можливість отримувати товари й послуги на кращих умовах, сприяють економічній ефективності шляхом створення сприятливого клімату для інновацій та технічного прогресу й запобігають антиконкурентній діяльності з боку компаній або керівництва держави.

Аналіз останніх досліджень i публікацій. Дослідженням порівняльних аспектів систем регулювання конкуренції в Україні та ЄС займаються українські вчені, а саме О. Бакалінська, Н. Горбаль, У. Когут, О. Микитин, А. Мовчан, С. Романишин, К. Смирнова, А. Суха, О. Шворак й ін. Однак більшість цих праць грунтуються на лише юридично-правових підходах і виконані в період до набуття чинності Угоди про асоціацію між Україною та СС і налагодження системи моніторингу іiі імплементації. Водночас існує необхідність здійснення функціонального аналізу механізмів регулювання конкуренції в СС та Україні з позицій виявлення трансформацій у системі регулювання 
конкуренції нашої держави під впливом саме нового формату відносин між сторонами, що перебуватиме в площині практичної реалізації в останні роки. Праць іноземних учених на відповідну тематику нами не виявлено.

Мета статті. Виходячи 3 наведених вище міркувань, метою статті визначаємо розкриття основних функціональних сторін конкурентної політики ЄС та обгрунтування впливу євроінтеграційного чинника на сучасний стан системи регулювання конкуренції в Україні.

Методика дослідження. Дослідження грунтується на загальнонаукових теоретичних та емпіричних методах, а саме методі системно-структурного аналізу (для виявлення основних сфер i механізмів регулювання конкуренції в СС та Україні, їх відображення в Угоді про асоціацію між Україною і СС та імплементації відповідних норм у національну систему конкурентного регулювання), порівняльного аналізу (для виявлення відмінних рис у системах регулювання конкуренції обох сторін), історико-ретроспективного аналізу (для відстеження динаміки трансформації системи регулювання конкуренції України під впливом євроінтеграційного чинника) й узагальнення (для підбиття підсумків системно-структурного, порівняльного та історикоретроспективного аналізу). Інформаційною основою дослідження слугували одно- й двосторонні правові акти у сфері регулювання конкуренції України та $€ \mathrm{C}$, наукові публікації вітчизняних учених і праці автора з відповідної тематики.

\section{2. РЕЗУЛЬТАТИ ДОСЛІДЖЕННЯ}

Система регулювання конкуренції в СС. Конкурентна політика СС формувалась у контексті забезпечення умов для ефективного функціонування єдиного ринку Союзу. Метою конкурентної політики $€ C €$ створення взаємоузгоджених принципів і правил конкуренції на спільному ринку, забезпечення ефективної взаємодії учасників спільного ринку, оптимізація розміщення й використання наявних ресурсів задля сприяння соціально-економічному та технологічному прогресу й конкурентоспроможності європейських виробників у світі.

Правову базу конкурентної політики СС формують установчі договори $\mathrm{CC}$, які утворюють основний правовий блок - первинне право ЄС, а саме ст. 101-109 Договору про функціонування ЄС (ДФСС). Первинне право відіграє головну роль, визначаючи підвалини й принципи регулювання конкуренції на ринку Союзу. Вторинне право 
має похідний характер і створюється на його основі (регламенти, директиви, рішення тощо). Воно не повинно суперечити первинному, а у випадку колізії переважну силу мають норми первинного права.

У формуванні єдиної конкурентної політики СС вирішальну роль відіграють Рада ЄС, Європейська комісія, Європейський парламент та Суд ЄС. Рада приймає рішення кваліфікованою більшістю за поданням Комісії й за погодженням Парламенту. Спеціалізованим структурним підрозділом Європейської комісії, який відповідає за реалізацію конкурентної політики Союзу, є Генеральний директорат із питань конкуренції. Комісія співпрацює 3 національними антимонопольними органами держав-членів за дво- й багатосторонніми схемами [1, с. 200$].$

Національні антимонопольні (спеціалізовані) чи судові (неспеціалізовані) органи держав-членів мають право розпочинати розслідування узгодженої практики чи домінування на ринку (статті 101-102 ДФЄС) самостійно. Вони можуть проводити його доти, доки Комісія не розпочне власний розгляд відповідної справи [2]. Національні органи можуть виносити рішення про відповідність певних узгоджених дій умовам звільнення. Існують також спеціальні форми співпраці комунітарних i національних структур, а саме Європейська конкурентна мережа, Європейська асоціація конкурентних відомств.

До провідних напрямів регулювання конкуренції на внутрішньому ринку СС відносять запобігання угодам й узгодженим діям, що обмежують конкуренцію, уключаючи картельну практику; недопущення зловживання домінуючим становищем на ринку; контроль за злиттями та поглинаннями підприємств (концентрацією); контроль за державною допомогою й створенням особливих умов для діяльності державних підприємств. Положення щодо всіх цих видів антиконкурентної поведінки містяться в ДФСС, крім положень щодо злиттів і поглинань. Останні врегульовуються Регламентом Ради 139/2004 [3].

Боротьба та запобігання угодам й узгодженим діям, що обмежують конкуренцію, займають провідне місце в конкурентній політиці ЄС. Практика таємних змов і картелів негативно відбивається на добробуті споживачів і створює значні труднощі для розбудови та функціонування єдиного ринку. Підвалини законодавчої бази антитрестівської політики закладені в ст. 101 ДФЄС. На забезпечення виконання цієї статті прийнято десятки актів вторинного законодавства.

Конкурентне право ЄС не забороняє підприємствам домінувати на ринку. Забороняється зловживання домінуючою позицією на ринку, тобто забороняються дії або сам факт існування фірми, що призводять 
до викривлення конкуренції, створюють перешкоди для торгівлі на внутрішньому ринку. На підприємства, які займають провідне становище на ринку, покладається особлива відповідальність за збереження конкуренції на ринку й за їхньою поведінкою особливо уважно слідкує Комісія. Основними правовими актами Союзу в цій сфері є ст. 102 ДФЄС, Регламент Ради 17/62, а також судові прецеденти.

Головна роль контролю за злиттями й поглинаннями проявляється не в масових їх заборонах, а у виявленні компромісних рішень, які попереджують можливі негативні наслідки таких дій. У разі виникнення загроз, які можуть перешкоджати вільній та ефективній конкуренції на загальноєвропейському ринку, Комісія пред'являє заявникам певні вимоги, виконання яких усуває негативні наслідки. Договори про злиття мають, зазвичай, суттєві позитивні ефекти на загальне економічне зростання, що є дуже актуальним для ЄС на сучасному етапі його розвитку [1, с. 202].

Регулювання державної допомоги є надзвичайно важливим питанням для єдиного ринку $\mathrm{EC}$, оскільки національна підтримка певних виробництв чи виробників в окремих країнах-членах робить їх більш конкурентоспроможними перед виробниками інших країн-членів, порушуючи тим самим правила чесної конкуренції. Проблема державної допомоги регулюється ст. 107-109 ДФЄС. Важливим критерієм є правило de minimums, тобто вимога досягнення мінімального рівня впливу, за якого включаються механізми захисту конкуренції. Державна допомога може розглядатися як сумісна зі спільним ринком, якщо вона має соціальний характер, ставить за мету відшкодування збитків від надзвичайних ситуацій, подолання економічної відсталості регіонів тощо.

Свроінтеграційний чинник у розвитку національної системи конкурентного регулювання. Основні цілі, принципи та механізми співпраці ЄС з Україною у сфері конкурентної політики сформульовані в низці двосторонніх документів й односторонніх актах Союзу. Вони охоплюють як сферу економічних перетворень у цілому, так і конкретні питання розвитку конкуренції. Імплементація положень конкурентного законодавства ЄС у норми законодавства України розпочалася фактично одразу після набуття суверенітету останньою. Так, у Законі України «Про обмеження монополізму та недопущення недобросовісної конкуренції у підприємницькій діяльності» (1992р.) низка положень була схожа за містом із положеннями конкурентного права ЄС [4].

«Спільна стратегія Свропейського Союзу щуодо Украӥни» (1999 р.) визначала основні напрями підтримки процесу економічних перетворень в Україні. Зокрема, ЄС зобов'язувався підтримувати зусилля України 
зі створення середовища, сприятливого для ділової діяльності, та підтримувати Україну в здійсненні соціально-економічних реформ.

У сфері безпосередньо конкуренції «Спільна стратегія Європейського Союзу щодо України» ставила за мету через механізми макрофінансової допомоги з боку ЄС сприяти зростанню відкритості економіки України, поліпшенню економічних умов, посиленню конкуренції, подальшій інтеграції господарства в європейську та глобальну економіку. ЄС також підтримує Україну шляхом заохочення невпинного зближення іiі законодавства із законодавством СС, зокрема в конкурентній політиці.

Європейський Союз має низку інструментів, використання яких сприяє формуванню ефективної системи конкурентного регулювання в Україні, її зближення з комунітарною конкурентною політикою. Зокрема, це відбувалося через програму TACIS. Пріоритетами програми TACIS були ядерна безпека та захист довкілля (26,4 \%), реструктуризація держпідприємств та розвиток приватного сектора $(19,1 \%)$, реформа державного управління, соціальної сфери та освіти $(9,6 \%)$, сільське господарство $(10,8 \%)$, енергетика $(11,2 \%)$, транспорт $(8,6 \%)$, консультації 3 економічної політики (5,4 \%), телекомунікації $(3,6$ \%) [5, с. 52].

Принципово нові можливості співпраці ЄС 3 Україною у сфері регулювання конкуренції виникають унаслідок прийняття Повідомлення Свропейської комісії «Ширша Свропа - сусідство: нові рамки відносин із новими східними та південними сусідами» (2003р.) [6]. Свропейська комісія виступає за «створення панєвропейського рівня відкритого та інтегрованого ринку, який функціонує за скоординованими або гармонізованими правилами...»

Аналіз Повідомлення Європейської комісії показує, що документ пропонує дві основні моделі зближення конкурентних правил СС та західних нових незалежних держав, у тому числі й України. Перша модель грунтується на прийнятті acquis communautaire як основи формування національних конкурентних політик. ЄС пропонує розроблену модель, на основі якої слід створити «функціонуючі ринки та спільні стандарти для промислових продуктів, послуг, транспорту, енергетичних i телекомунікаційних мереж, захисту довкілля й прав споживачів, здоров'я, вимог до умов праці та якості». Це найкоротший та найефективніший шлях до зближення конкурентної політики України з комунітарною політикою в цій сфері. Саме від розвитку реформ в Україні, у тому числі у сфері конкурентного регулювання, залежатиме від того, наскільки близько вона підійде до $Є С$, не будучи його членом.

Друга модель - це зближення регуляторних механізмів у межах Спільного європейського економічного простору. Цей підхід не 
передбачає домовленостей про терміни правового та регуляторного зближення, має більш повільний характер. Він може здійснюватися за умов співпраці $6 C, 3$ одного боку, та Росії, України, Білорусі й Казахстану - із другого. Угода про формування Єдиного економічного простору ставить за мету «гармонізацію законодавства Сторін тією мірою, якою це потрібно для функціонування Єдиного економічного простору, уключаючи торговельну та конкурентну політику», перехід до «єдиної конкурентної політики».

Україна обрала першу модель відносин, коли за мету ставиться адаптація законодавства України до законодавства ЄС. Ще в листопаді 2002 р. Верховна Рада України ухвалила Закон «Про Конц̧епцію Загальнодержавної програми адаптації законодавства України до законодавства $Є C »[7]$. Згодом події Революції гідності підтвердили намір українського народу інтегруватися до ЄС шляхом запровадження європейських цінностей і стандартів в усі сфери життя суспільства.

Основним двостороннім документом, який фіксує зобов'язання сторін, у тому числі у сфері конкуренції, довгий час була Угода про партнерство та співробітництво (УПС) між Україною і Свропейським Співтовариством [8]. Вона мала як спільні риси, зумовлені позицією ЄС, так і значні відмінності від так званих Європейських угод $Є С$ із країнами Центральної Європи. Загалом УПС мала менш вимогливі зобов'язання й більш загальні положення щодо регулювання конкуренції, ніж Європейські угоди.

Питань конкуренції безпосередньо стосувалася лише одна ст. 49 УПС. Вона зобов'язувала сторони вдатися до зменшення або усунення обмежень щодо конкуренції, які спотворюються або самими підприємствами, або через утручання держави, оскільки ці обмеження можуть негативно впливати на двосторонні торговельні зв'язки. При цьому відокремлювалося чотири сфери, де можливе спотворення конкуренції: антиконкурентна поведінка підприємств приватного сектору; державна допомога; поведінка державних монополій комерційного характеру; поведінка державних підприємств або підприємств, яким надані виняткові права. Порівняно з положеннями Європейських угод, у структурі УПС значно більше уваги приділялося саме державній допомозі, оскільки Україна як країна 3 перехідною економікою зберігала значне державне втручання в економіку, мала невисокий рівень економічної лібералізації.

Визначення передумов i сфер регулювання конкуренції в УПС 3 Україною переважно збігалося за структурою 3 принципами комунітарної конкурентної політики, які закладені в ст. 101, 102, 106 
i 107 (попередні ст. 81, 82, 86, 87) Договору про функціонування ЄС. Водночас УПС мала загальний характер і недостатньо деталізовані положення щодо регулювання конкуренції та по-друге, не охоплювала механізми протидії антиконкурентним діям підприємств і державних структур. Це означало, що кожна сторона повинна використовувати свій наявний механізм регулювання. Зрозуміло, що за умов відсутності механізмів протидії антиконкурентним діям, які б повністю збігалися, між сторонами можуть виникати суперечності щодо визначення як самого характеру порушення, так і інструментів їх урегулювання.

У Спільній заяві Саміту Європейський Союз - Україна від 4 липня 2002 р. ЄС підтвердив свою готовність продовжувати співпрацю й підтримку України у сфері законодавчої апроксимації, що $є$ одним із ключових елементів інтенсифікації відносин між Україною та ЄС. Спільна доповідь із виконання Угоди про партнерство й співробітництво між Україною та $Є С$ відзначила прогрес в адаптації законодавства у сферах конкуренції, банківської системи, фінансових послуг, Земельного кодексу й права інтелектуальної власності.

Загалом, за висновками експертів-правників, система захисту економічної конкуренції в Україні станом на 2016 р. давала змогу виконувати завдання, які стояли перед конкурентними органами [9, с. 130]. ОЕСР та ЮНКТАД теж позитивно оцінювали вітчизняну політику у сфері конкуренції [10, с. 188].

Із набуттям чинності Угодою про асоціацію між Украӥною та $\boldsymbol{E C}$ (1 вересня 2017 р.) перед нашою державою поставлено нові чіткі завдання у сфері регулювання конкуренції та строки їх виконання. Основні прогалини, які мали бути усунені в процесі імплементації Угоди про асоціацію, діляться на вдосконалення норм матеріального й процесуального права [11, с. 35]. Глава 10 розділу IV (ст. 253-267) Угоди стосується безпосередньо питань регулювання конкуренції. У ст. 256 ідеться про те, що Україна наближує своє законодавство про конкуренцію та практику застосування до асquis $\mathrm{CC}$. Вона це робить згідно з визначеним графіком (табл. 1).

Угода про асоціацію спонукає Україну реформувати систему надання державної допомоги. У ст. 267 ідеться про те, що Україна протягом трьох років з дати набрання чинності Угодою має прийняти національне законодавство про державну допомогу та створити незалежний у своїй діяльності орган, який матиме повноваження, необхідні для застосування в повному обсязі статті 262 Угоди (положення про сумісну й несумісну допомогу в ринкових умовах) [12]. 
Україна протягом п’яти років із дати набрання чинності Угодою має створити повний реєстр схем державної допомоги, яка надавалася до створення вищезазначеного органу, та має привести ці схеми допомоги у відповідність до критеріїв, визначених у статтях 262 і 264 Угоди, протягом строку не більше ніж сім років із дати набрання чинності цією Угодою [12].

Таблиия 1

\section{Графік гармонізації конкурентного законодавства України до норм СС згідно з Угодою про асоціацію*}

\begin{tabular}{|c|c|c|}
\hline $\begin{array}{c}\text { Нормативний } \\
\text { акт } \mathbf{C C}\end{array}$ & Сфера застосування & $\begin{array}{c}\text { Строки виконання } \\
\text { Україною }\end{array}$ \\
\hline $\begin{array}{l}\text { Стаття } 30 \\
\text { Регламенту Ради } \\
\text { (ЄС) № } 1 / 2003\end{array}$ & $\begin{array}{l}\text { Угоди й узгоджена } \\
\text { практика між } \\
\text { підприємствами }\end{array}$ & $\begin{array}{l}\text { Протягом трьох } \\
\text { років після набрання } \\
\text { чинності цією Угодою }\end{array}$ \\
\hline $\begin{array}{l}\text { Статті } 1 \text { та } 5 \text { (1) - } \\
\text { (2) Регламенту Ради } \\
\text { (СС) № } 139 / 2004\end{array}$ & $\begin{array}{l}\text { Злиття й поглинання } \\
\text { підприємств }\end{array}$ & $\begin{array}{l}\text { Протягом трьох } \\
\text { років після набрання } \\
\text { чинності цією Угодою }\end{array}$ \\
\hline $\begin{array}{l}\text { Стаття } 20 \\
\text { Регламенту Ради } \\
\text { (СС) № 139/2004 }\end{array}$ & $\begin{array}{l}\text { Злиття й поглинання } \\
\text { підприємств }\end{array}$ & $\begin{array}{l}\text { Протягом трьох } \\
\text { років після набрання } \\
\text { чинності цією Угодою }\end{array}$ \\
\hline $\begin{array}{l}\text { Статті } 1,2,3,4,6, \\
7 \text { та } 8 \text { Регламенту } \\
\text { Комісії (СС) } \\
\text { № 330/2010 }\end{array}$ & $\begin{array}{l}\text { Вертикальні угоди } \\
\text { та узгоджені дії } \\
\text { підприємств }\end{array}$ & $\begin{array}{l}\text { Протягом трьох } \\
\text { років після набрання } \\
\text { чинності цією Угодою }\end{array}$ \\
\hline $\begin{array}{l}\text { Статті } 1,2,3,4,5, \\
6,7 \text { та } 8 \text { Регламенту } \\
\text { Комісії (СС) } \\
\text { № } 772 / 2004\end{array}$ & $\begin{array}{l}\text { Угоди про передачу } \\
\text { технологій }\end{array}$ & $\begin{array}{l}\text { Протягом трьох } \\
\text { років після набрання } \\
\text { чинності цією Угодою }\end{array}$ \\
\hline
\end{tabular}

* Складено автором за: [12].

Згідно з даними звітів про виконання Угоди про асоціацію у 20161019 pp. у частині впровадження норм щодо регулювання конкуренції взяті Україною зобов'язання виконані. Наприклад, збільшені порогові вартісні показники, під час досягнення яких потрібно отримувати дозвіл на концентрацію. Також, залучивши кваліфікованих фахівців, змінили систему визначення штрафів за порушення конкурентного законодавства [13]. 
Зазнали змін правові та організаційні засади діяльності Антимонопольного комітету України, який став більш відкритий до бізнесу, імплементовано низку актів $С$ із питань конкуренції [13]. Відповідальним органом за виконання ст. 253-267 Угоди про асоціацію визначено Антимонопольний комітет України [15].

Орієнтуючись на європейські цінності й пріоритети у сфері регулювання конкуренції, наша держава повинна забезпечити [16, с. 23-24]:

- зниження рівня монополізації та концентрації товарних ринків;

- інтенсифікацію вступу нових суб’єктів господарювання на товарні ринки;

- мінімізацію негативного впливу на економічну конкуренцію, що виникає внаслідок антиконкурентних дій органів державної влади й органів місцевого самоврядування, а також недостатньо ефективного державного регулювання товарних ринків;

- зменшення негативного впливу на економічну конкуренцію внаслідок порушення вимог законодавства про захист економічної конкуренції, захист інтересів суб'єктів господарювання й споживачів;

- прийняття рішень із питань економічної політики з урахуванням цілей і завдань політики розвитку конкуренції;

- гармонізацію законодавства про захист економічної конкуренції з європейським законодавством у відповідній сфері;

- формування в суспільстві позитивного ставлення до економічної конкуренції як фундаментальної суспільної цінності.

\section{3. ВИСНОВКИ ТА ПЕРСПЕКТИВИ ПОДАЛЬШИХ ДОСЛІДЖЕНЬ}

Європейський Союз зацікавлений у сусідстві з країнами, які мають позитивну соціально-економічну динаміку, успішно розв'язують проблеми сталого розвитку. До таких країн належить також Україна. Основні цілі, принципи та механізми співпраці ЄС з Україною у сфері конкурентної політики сформульовані у низці одно- й двосторонніх документів. Вони охоплюють як сферу економічних перетворень у цілому, так і конкретні питання розвитку конкуренції. Головним із них сьогодні є Угода про асоціацію між Україною та $€ C$, у якій прописані чіткі строки щодо гармонізації Україною національних норм регулювання конкуренції до стандартів ЄС. Формально сфера регулювання конкуренції $є$ однією 3 найбільш гармонізованих до стандартів $€$, однак практичне дотримання прийнятих європейських конкурентних норм залишається актуальним для нашої держави питанням. 


\section{СПИСОК ВИКОРИСТАНИХ ДЖЕРЕЛ}

1. Бояр, А. О. (2008). Торговельно-економічні відносини між Україною та СС: регулювання зовнішньої торгівлі і конкурениії в умовах єдиного ринку СС / за заг. ред. М. Бойцуна та ін. Київ: Міленіум, 384 с.

2. Council Regulation (EC). No 1/2003 of 16 December 2002 on the implementation of the rules on competition laid down in Articles 81 and 82 of the Treaty (Text with EEA relevance) (2003). OJ L 1, 04.01.2003, 1-25. URL: https://eur-lex.europa.eu/legal-content/ EN/TXT/?uri=CELEX\%3A32003R0001\&qid=1620641776594

3. Council Regulation (EC) No 139/2004 of 20 January 2004 on the control of concentrations between undertakings (the EC Merger Regulation) (Text with EEA relevance) (2004). OJ L 24, 29.01.2004, 1-22. URL: https://eur-lex.europa.eu/legal-content/EN/TXT/? uri $=$ CELEX\%3A32004R0139\&qid=1620643683697

4. Шворак, О. (2016). Конкурентна політика ЄС та українська євроінтеграція. Юридична газета, 36 (534). URL: http://kmp.ua/uk/analytics/press/konkurentana-polityka-yes-ta-ukrayinska-yevrointegratsiya/\#

5. Старостенко, Г. Г., Подсядло, Л. П., Квасницька, Р. С. (2009). Сучасні форми та перспективи співробітництва України з державами Свропейського Союзу. Національне господарство України: теорія та практика управління, 46-54.

6. Communication from the Commission to the Council and the European Parliament - Wider Europe - Neighbourhood: A New Framework for Relations with our Eastern and Southern Neighbours (2003). COM/2003/0104 final. URL: https://eur-lex.europa.eu/legalcontent/AUTO/?uri=CELEX:52003DC0104\&qid=1620634661425\&rid=1

7. Закон України «Про Конщепџію Загальнодержавної програми адаптаиії законодавства України до законодавства ЄС» (2003). URL: https://zakon.rada.gov.ua/ laws/show/228-15\#Text

8. Угода про партнерство і співробітництво між Украӥною $і$ Європейськими співтовариствами та їх державами-членами (1994). URL: https://zakon.rada.gov.ua/ laws/show/998_012\#Text

9. Мовчан, А. В. (2016). Правове регулювання захисту економічної конкуренції в умовах європейської інтеграції. Право.иа, 1, 127-131.

10. Горбаль, Н. І., Романишин, С. Б., Когут, У. І. (2016). Імплементація в Україні антимонопольного законодавства Європейського Союзу. Науковий вісник НЛТУ України, вип. 26.2, 182-190.

11. Смирнова, К. (2015). «Клаузула про конкуренцію» в Угоді про асоціацію між Україною та ЄС. Вісник Львівського університету. Серія: Міжнародні відносини, вип. 36, 35-49.

12. Угода про асоиіацію між Україною, з однієї сторони, та Європейським Союзом, Свропейським співтовариством з атомної енергії $і$ ӥхніми державами-членами, $з$ іншої сторони (2014). URL: https://zakon.rada.gov.ua/laws/show/984_011\#Text

13. Горбаль, Н. І., Микитин, О. З., Суха, А. Я. (2019). Державне регулювання конкуренції в Україні та СС. Бізнес Інформ, 4, 66-71. URL: https://doi.org/10.32983/22224459-2019-4-66-71

14. Бакалінська, О. (2020). Розвиток конкурентного законодавства і права України в умовах європейської інтеграції. Платформа стратегічної та законодавчої аналітики «Координата», 04.02.2020. URL: https://coordynata.com.ua/rozvitok-konkurentnogo-zakonodavstva-i-prava-ukraini-v-umovah-evropejskoi-integracii 
15. Звіти про виконання Угоди про асоціацію між Україною та СС (2019). URL: https://www.kmu.gov.ua/diyalnist/yevropejska-integraciya/vikonannya-ugodi-pro-asociaciyu/zviti-pro-vikonannya-ugodi-pro-asociaciyu

16. Концепція державної політики розвитку та захисту економічної конкуренції в Україні (проект) (2019). Антимонопольний комітет Украӥни, 24 с. URL: http://www. amc.gov.ua/amku/doccatalog/document?id=146848\& schema=main

\section{THE EUROPEAN UNION IMPACT ON THE FORMATION OF THE COMPETITION REGULATION SYSTEM IN UKRAINE}

Integration into the European Union has been one of the defining priorities of Ukraine's foreign policy since the first years of its sovereignty. Therefore, European integration progress in various spheres of society is quite interesting and relevant object of research and scientific substantiation. The field of competition regulation is no exception in this respect. The article examines the basic features of the EU competition regulation system. A historical-retrospective analysis of the evolution of the national system of competitive regulation of Ukraine in the context of the influence of the European integration factor is carried out. It is revealed that although its formation from the very beginning was in accordance with EU principles and norms, before the entry into force of the Association Agreement between Ukraine and the EU (01.09.2017) there were some differences between the two systems. They, however, were corrected in the first three years of implementation of this Agreement by the Ukrainian side. In particular, the system of state aid in Ukraine was significantly reformed (a register of state aid schemes was created, they were brought into line with the criteria set by the Agreement); the thresholds for mergers of companies were increased; the system of determination of fines for the competition rules violations was reformed; competition legislation and the organizational principles of the Antimonopoly Committee of Ukraine were improved. The latter is the main body responsible for implementation of the competition rules referred to in the Association Agreement. It is also revealed that the normative sphere of competition regulation in Ukraine is one of the most harmonized with the EU standards today, but the practical observance of the adopted European competition norms remains a topical issue for our country.

The article prepared within the Jean Monnet Chair Activity «EU Studies at Lesya Ukrainka Volyn National University» of the Erasmus+ Programme of the European Union» (№ 611478-EPP-1-2019-1-UA-EPPJMO-CHAIR).

Key words: competition; Ukraine; European Union; regulation; system; agreement; association. 


\section{REFERENCES}

1. Boiar, A. O. (2008). Commercial and economic relations between Ukraine and the EU: external trade and competition regulation in terms of the common market / ed. M. Boitsun et al. Kyiv: Millenium, 384 p. (in Ukrainian).

2. Council Regulation (EC) No 1/2003 of 16 December 2002 on the implementation of the rules on competition laid down in Articles 81 and 82 of the Treaty (Text with EEA relevance) (2003). OJ L 1, 04.01.2003, 1-25. URL: https://eur-lex.europa.eu/legal-content/ $\mathrm{EN} / \mathrm{TXT} /$ ?uri=CELEX\%3A32003R0001\&qid=1620641776594 (in English).

3. Council Regulation (EC) No 139/2004 of 20 January 2004 on the control of concentrations between undertakings (the EC Merger Regulation) (Text with EEA relevance) (2004). OJ L 24, 29.01.2004, 1-22. URL: https://eur-lex.europa.eu/legal-content/EN/TXT/? uri=CELEX\%3A32004R0139\&qid=1620643683697 (in English).

4. Shvorak, O. (2016). Competition policy of the EU and Ukrainian European integration. Yurydychna hazeta, 36 (534) URL: http://kmp.ua/uk/analytics/press/konkurentanapolityka-yes-ta-ukrayinska-yevrointegratsiya/\# (in Ukrainian).

5. Starostenko, H. H., Podsiadlo, L. P., Kvasnytska, R. S. (2009). Contemporary forms and prospects of cooperation between Ukraine and the European Union member states. Natsionalne hospodarstvo Ukrainy: teoriia ta praktyka upravlinnia, 46-54. (in Ukrainian).

6. Communication from the Commission to the Council and the European Parliament - Wider Europe -Neighbourhood: A New Framework for Relations with our Eastern and Southern Neighbours (2003). COM/2003/0104 final. URL: https://eur-lex.europa.eu/legalcontent/AUTO/?uri=CELEX:52003DC0104\&qid=1620634661425\&rid=1 (in English).

7. Law of Ukraine «On the Concept of Statewide programme of adaptation of legislation of Ukraine to the EU legislation»(2003). URL: https://zakon.rada.gov.ua/laws/ show/228-15\#Text (in Ukrainian).

8. Partnership and Cooperation Agreement between Ukraine and the European Communities and their Member States (1994). URL: https://zakon.rada.gov.ua/laws/ show/998_012\#Text (in Ukrainian).

9. Movchan, A. V. (2016). Legal regulation of the economic competition protection under conditions of European integration. Pravo.ua, 1, 127-131 (in Ukrainian).

10. Horbal, N. I., Romanyshyn, S. B., Kohut, U. I. (2016). Implementation of antimonopoly legislation of the European Union in Ukraine. Naukovyi visnyk NLTU Ukrainy, 26.2, 182-190 (in Ukrainian).

11. Smyrnova, K. (2015). «Clause about competition» in the Association agreement between Ukraine and the EU. Visnyk Lvivskoho universytetu. Seriia mizhnarodni vidnosyny, 36, 35-49 (in Ukrainian).

12. Association agreement between Ukraine, on one side, and the EU, Euratom and their Member States, on the other side (2014). URL: https://zakon.rada.gov.ua/laws/ show/984_011\#Text (in Ukrainian).

13. Horbal, N. I., Mykytyn, O. Z., Sukha, A. Ya. (2019). State regulation of competition in Ukraine and the EU. Business Inform, 4, 66-71. URL: https://doi.org/10.32983/22224459-2019-4-66-71 (in Ukrainian).

14. Bakalinska, O. (2020). Development of competition legislation and law of Ukraine under conditions of the European integration. Platforma stratehichnoi ta zakonodavchoi analityky «Koordynata», 04.02.2020. URL: https://coordynata.com.ua/rozvitok-konkurentnogo-zakonodavstva-i-prava-ukraini-v-umovah-evropejskoi-integracii (in Ukrainian). 
15. Reports on implementation of the Association agreement between Ukraine and the EU (2019). URL: https:/www.kmu.gov.ua/diyalnist/yevropejska-integraciya/vikonannyaugodi-pro-asociaciyu/zviti-pro-vikonannya-ugodi-pro-asociaciyu (in Ukrainian).

16. Conception of state policy on development and protection of economic competition in Ukraine (draft) (2019). Antimonopoly Committee of Ukraine, 24 p. URL: http://www. amc.gov.ua/amku/doccatalog/document? $i d=146848 \&$ schema=main (in Ukrainian).

Матеріал надійшов до редакиіï 15.01.2021 p.

УДК 32.019.51

\section{Андрій Гачкевич,}

кандидат юридичних наук, доцент кафедри міжнародної інформації,

Національний університет «Львівська політехніка»,

ORCID ID 0000-0001-7520-7426

andrii.o.hachkevych@1pnu.ua

\section{Влада Сірош,}

бакалаврант кафедри міжнародної інформації,

Національний університет «Львівська політехніка»,

ORCID ID 0000-0003-0868-3224

vlada.sirosh.mv.2017@1pnu.ua

\section{Анна Шевчук,}

бакалаврант кафедри міжнародної інформації,

Національний університет «Львівська політехніка»,

ORCID ID 0000-0002-6554-2287

anna.shevchuk.mv.2017@1pnu.ua

DOI 10.29038/2524-2679-2021-01-358-370

\section{ТЕОРЕТИКО-МЕТОДОЛОГІЧНІ ОСНОВИ ВИКОРИСТАННЯ ДЕРЖАВАМИ БРЕНДИНГУ ТА РЕПУТАЦЙНОГО МЕНЕДЖМЕНТУ ЯК ІНСТРУМЕНТІВ УПРАВЛІННЯ ПРИВАТНИМИ КОМПАНІЯМИ}

У статті вивчено процеси управління такими нематеріальними ресурсами держави, як бренд та репутація. Брендинг і репутаційний менеджмент уже тривалий час використовуються для підвищення успішності приватних компаній, а віднедавна й для розвитку могутності держав на міжнародній арені. Водночас наявність істотних відмінностей між обома суб'єктами зумовлює потребу в розробиі інших підходів до зміцнення авторитету держав, ніж просування компаній на ринках. Зважаючи на 